\title{
PSYCHE.
}

ORGAN OF THE CAMBRIDGE ENTOMOLOGICAL CLUB. EITTED BY B. PICKMAN MANN.

Vol. I.] Cambridge, Mass., November, 1874. [No. 7.
[N

\section{Summer Butterflies at the White Mountains.}

I am indebted to Mr. Scudder for the privilege of examining the advance sheets of his forthcoming paper on "The Distribution of the Insects in New Hampshire." His labors on the mountain fam have been so thorough that nearly all its characteristic features have been recorded, at least so far as the Diurnal Lepidoptera and Orthoptera are concerned. Still the collections made during the excursion of the Cambridge Entomological Club to Mt. Washington, from June 26 to July 11, this year, show the occurrence of one new form, and furnish data for the determination of the time of appearance and relative abundance of many others. The following is a list of the butterflies taken at that time.

Eneis semidea Say. Nothing new was discoiered in regard to this species. The first specimens appeared about July 1st, and in a few days it became very abundant. Specimens were taken as low down as Sanborn's camp, or about the middle of Mr. Scudder's sub-alpine region. As semidea was the only butterfly captured in numbers, which has its habitat on the upper portion of the mountain, but little can be produced, as far as the Diurnals are concerned, either in fitror of, or against the presence of two distinct faunal areas above the tree line; but in a list of the Noctuidie to appear in a future number of Psxche, I have some observations to offer on the distribution of the moths, which bear on this point.

Enodia eurydice Linn. Two specimens captured in low swampy fields, - one below the first saw mill, on June 29, another near the Glen House, on July 2.

Phyciodes tharos Drury. Common in the Glen.

Phyciodes harrisii Scudd. This species was found inhabiting 
the same restricted localities in which $\mathrm{Mr}$. Scudder observed the larva in the spring. From June 27 to July 4 the imagines were emerging, and in fine condition. After this date many poor ones began to be found.

Phycindes nycteis Doubl. \& IIew. Two in rery pror condition were taken on July 2, on the Glen road, abunt one mile before the second saw-mill.

Meliteca phaeton Drury. Found abundantly on July t, in a swamp situated on the Glen road, about four miles from Gorham. On July is specimens were also taken just above the Glen House, in a similar locality.

Argynnis myrinc Cram. More or less common in swamps in the valley.

Argynnis montinus Scudd. A specimen which I have not seen, probably of this species, was caught above the Halt IV ay House, by Mr. Dimmock on July 12, after the rest of the party had gone.

Aryynnis atlantis Edw. Began to appear about Jume 2!), and in a few days became common. It was taken throughout the valley, and about two miles up the momtain.

('To be continued.)

II. K. Morrison.

Novertifs in Ammerst, Mass. - So far as known, the following species have not been taken hitherto in this vicinity: Vanessor corrlui. $q$. July 28 th, and both sexes afterward. Junonia coenia, $\mathscr{q}$, July 25 th, on thistles alar expanse $1.80 ; \delta^{\circ}$, somewhat worn, Aug. 4 th, caught flying after severe chase-al. ex. 1.90 ; several others seen on roads. Euptoieta clautia, \&, on thistles, Augr. 3d-al. ex. 2.40. Cyaniris sp?, \&, on Mt. Holyoke, June 25th - like neqlecta, but uniform dusky gray beneath, a lighter shade edging the spots, and preceding the crescents; above, dusky gray in place of white. Cyaniris sp??, 8 , Pelham hills, Aug. 17th - like neglecta, except the primaries above are much deeper blue, mixed with dusky. Neither of these is lucia, nor arrees satisfactorily with named specimens of violacea from W. II. Edwatrds. In regard to violacea, I have a s specimen, dated June 1, found here. Achalarus Lypirlas, o, on Mt. Holyoke. Jume 25th. Pholisora Catullus. $\delta$, in .June; not rare on and after. July 30. Anthomaster Leonardus, $4 \delta^{\circ}$, mentioned only as early for the species as recordenl, Pelham hills, Aug. 17th. Prof. S. II. Peabody has taken Amblyscirtess samoset and Poanes Massasoit in this place, one specimen of each. H. IV. Parker. 

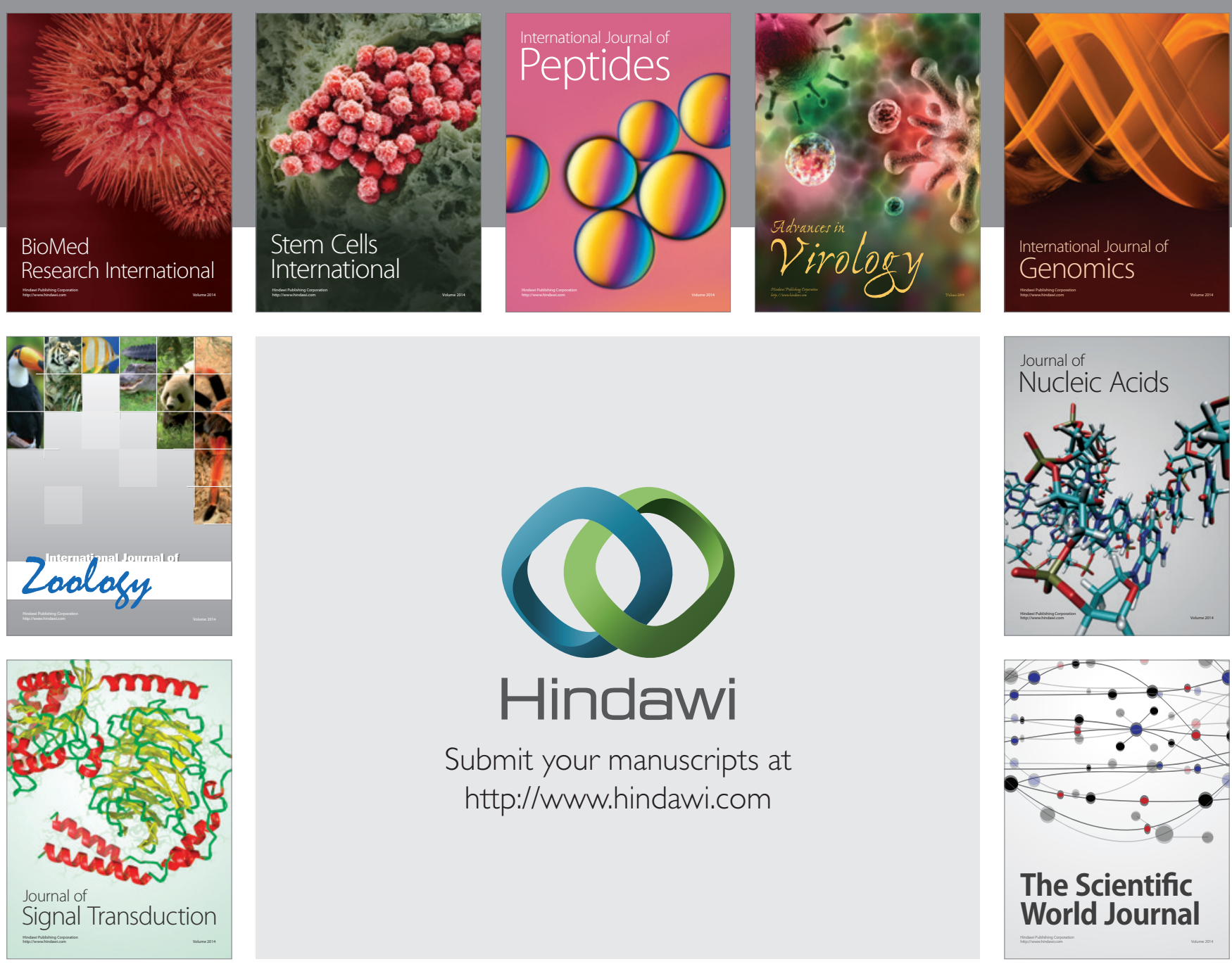

Submit your manuscripts at

http://www.hindawi.com
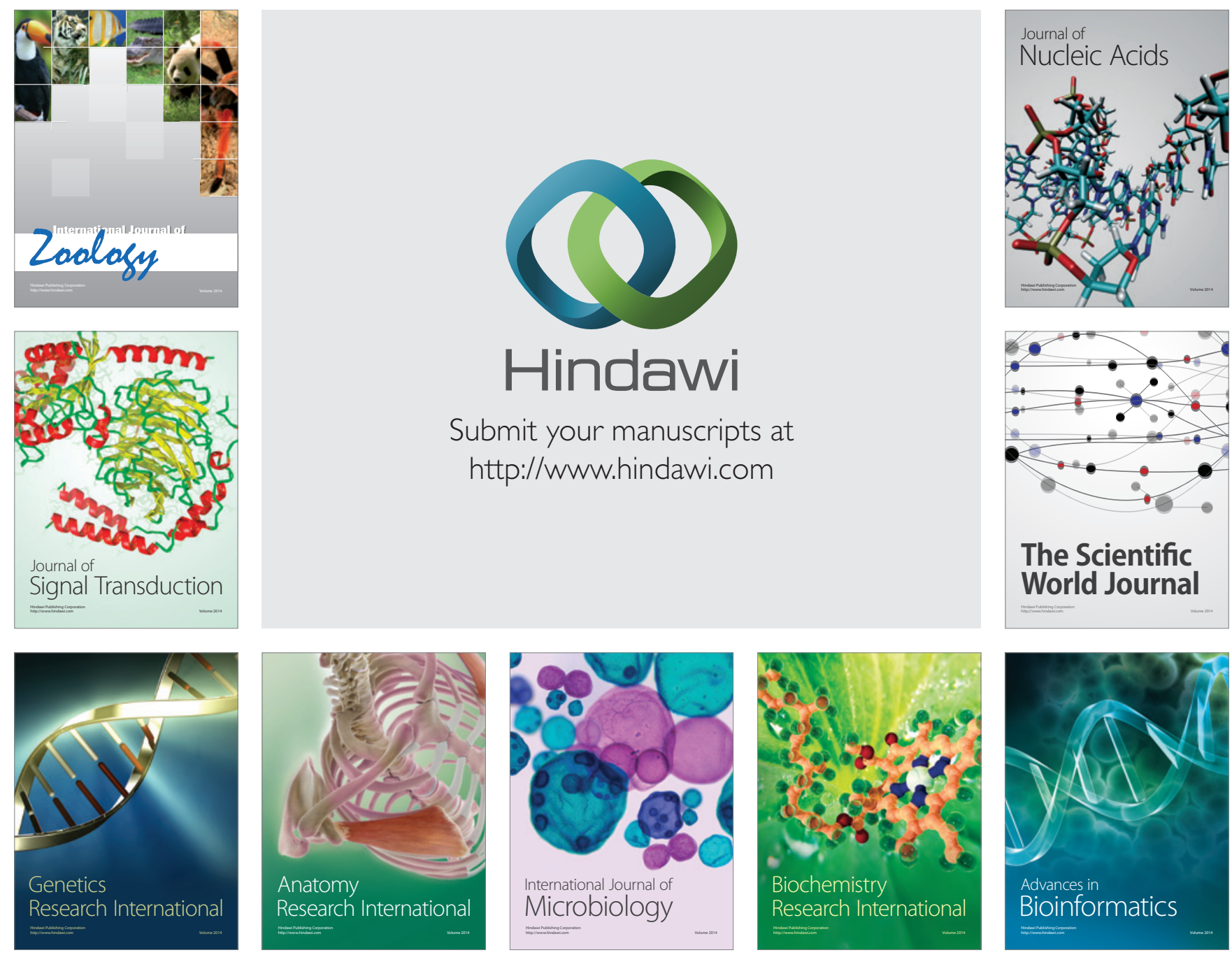

The Scientific World Journal
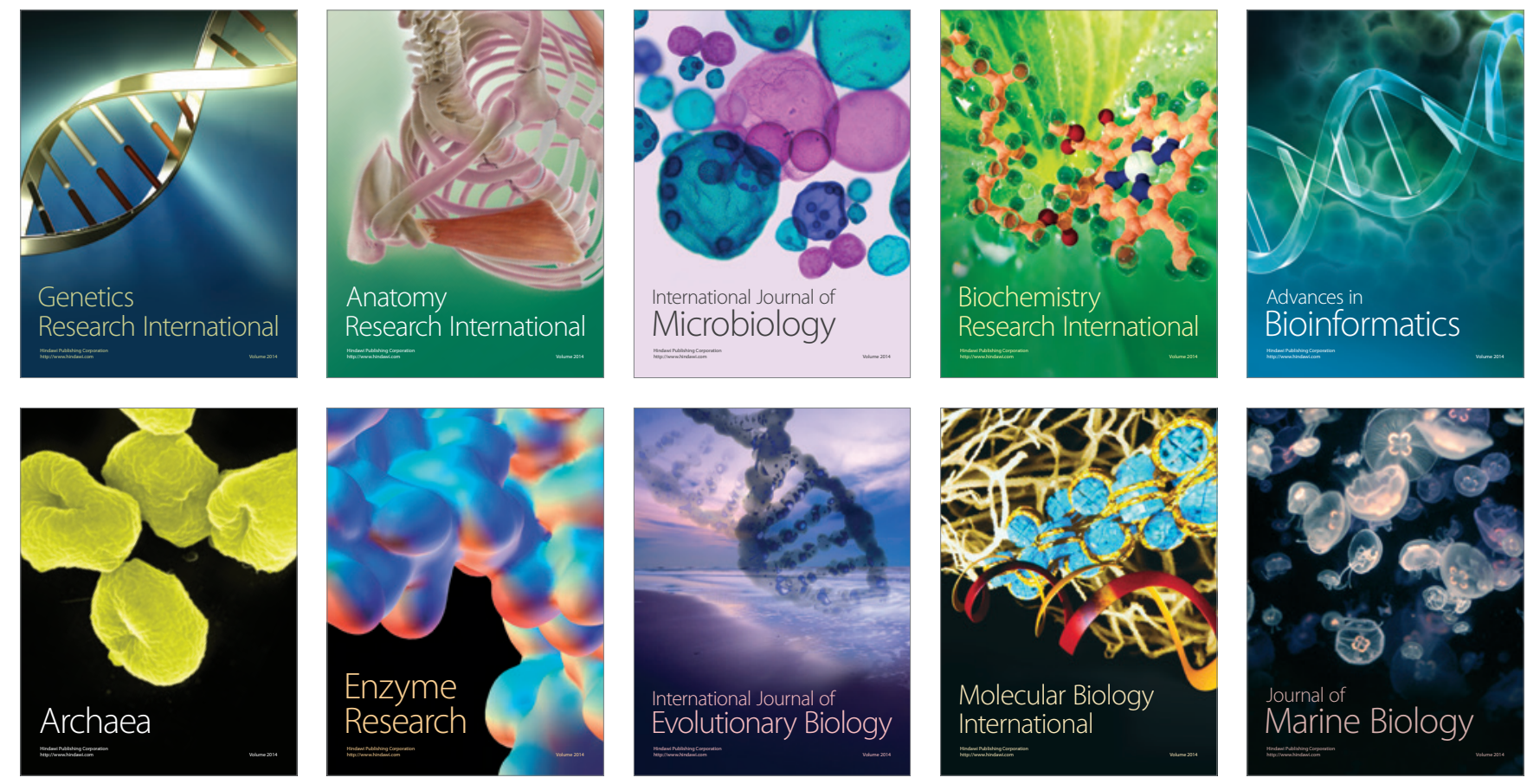